\title{
КОНТРОЛЬ ЭФФЕКТИВНОСТИ ВАКЦИНОПРОФИЛАКТИКИ ИНФЕКЦИОННОГО БРОНХИТА КУР В ПТИЦЕВОДЧЕСКИХ ХОЗЯЙСТВАХ РЕСПУБЛИКИ КРЫМ
}

С.И. Данильченко (фото)

к.В.н., руководитель лабораторно-диагностического центра

М.А. Пасунькина

к.В.н., заведующая лабораторией диагностики болезней животных

И.Б. Ионкина

ведущий биолог лаборатории диагностики болезней животных

Н.Г. Кошарный

руководитель сектора приёма проб патологических материалов

Филиал ФГБУ «Федеральный центр охраны здоровья животных» в Республике Крым, г. Симферополь

Инфекционный бронхит кур, вакцины, сыворотка крови, серологический мониторинг, напря⿻еённость иммунитета

Avian infectious bronchitis, vaccines, serum, serological monitoring, immunity intensity
Среди вирусных болезней птиц особое место занимает инфекционный бронхит кур, который наносит значительный экономический ущерб птицеводству. Болезнь впервые была зарегистрирована в 1931 году в США и с тех пор распространилась повсеместно, где есть промышленное птицеводство [1].

Инфекционный бронхит кур (ИБК) - остро протекающая высококонтагиозная болезнь вирусной этиологии, сопровождающаяся поражениями респираторного тракта и мочеполовой системы птиц. Формы проявления заболевания в основном зависят от возраста птиц: у молодняка ИБК проявляется респираторным и уремическим синдромами, у кур - поражением репродуктивных органов, что ведёт к длительному снижению яичной продуктивности [2].

ИБК на протяжении многих лет остаётся одной из наиболее широко распространённых вирусных болезней кур всех кроссов и возрастов. Этому способствуют высокая инфекционность, множественность генотипов, быстрая изменчивость вируса, широкое применение живых вакцин, высокая плотность содержания птицы [3].

В настоящее время специфическая профилактика в комплексе с общими оздоровительными мероприятиями имеет большое значение в борьбе с ИБК. Наряду со специфической профилактикой строгая технологическая дисциплина и высокая ветеринарно-санитарная культура производства, полноценное кормление птицы способствуют созданию в стаде прочной иммунной защиты $[3,4]$. Вакцинация не всегда бывает успешной, поскольку сложно обеспечить доставку эффективной дозы всем птицам без исключения при использовании методов массовой вакцинации живыми вакцинами [3].

Проведённый на территории Российской Федерации мониторинг вируса ИБК с помощью ОТ-ПЦР и секвенирования указывает на доминирующее распространение изолятов генотипа Массачусетс - до 40\%. 
Довольно часто (5-15\%) также встречаются изоляты генотипа 793/B, D207, D212, D274, QX, B1648. Данное распределение изолятов на территории РФ несколько отличается от распределения на территории Европейского Союза, где доминируют генотипы 793/B, Массачусетс, FR-94, QX и Италия-02 [3, 4, 5].

В дальнейшем возможно изменение картины распределения в связи с глобализацией птицеводства и завозом молодняка птицы из-за рубежа, преимущественно из Европы, а также в результате участившегося использования вакцин на основе серотипа 4/91, IB88, IBvar импортного производства, которые могут послужить причиной возникновения полевых вирусов ИБК [5].

На сегодняшний день для специфической профилактики ИБК используют преимущественно живые и инактивированные вакцины из штаммов серотипа Массачусетс. Их протективная активность против гомологичных полевых изолятов хорошо изучена, однако они обеспечивают лишь частичную защиту от заражения вариантными вирусами ИБК.

В последнее время появилось много экспериментальных доказательств существующей перекрёстной защиты между различными штаммами. Например, иммунизация штаммами Ma5 серотипа Массачусетс и серотипа 793В защищают птиц от высокопатогенного штамма QX (вакцинация при этом происходит одним, ревакцинация другим штаммом). Объяснением данного факта является то, что большая часть вирусного генома (основную массу которого составляет белок нуклеокапсида N) остаётся неизменной, несмотря на различия в S1 белке. Поэтому считают, что это может быть причиной того, что вакцины ИБК из некоторых серотипов могут создавать защиту против штаммов ИБК, не принадлежащих этому серотипу. Явление такого синергидного действия вакцин получило название протектотип $[2,6]$.

Следовательно, для гарантированной защиты от вируса ИБК необходимо подобрать оптимальную схему профилактики из имеющихся вакцин. Регулярные серологические исследования напряжённости иммунитета к ИБК на птицеводческих предприятиях помогают обнаружить и диагностировать какие-либо сбои с тем, чтобы предпринять корректирующие меры, если вакцинация оказалась неудачной.

Целью наших исследований было проведение серологического мониторинга инфекционного бронхита кур и изучение гуморального иммунитета к ИБК у птицы разных возрастных групп.

\section{Материалы и методы}

Исследования проводились на базе лаборатории диагностики болезней животных (ЛДБЖ) Лабораторно-диагностического центра Филиала ФГБУ «Федеральный центр охраны здоровья животных» в Республике Крым в течение 20172018 гг.

Материалом для исследований служили образцы сывороток крови от кур разных возрастных групп, поступившие из Государственного унитарного предприятия Республики Крым «Учебно-опытный племенной птицеводческий завод им. Фрунзе» (ГУП РК «УОППЗ им. Фрунзе») Сакского района и ООО СП «Октябрьское» Красногвардейского района.

Определение антител к вирусу ИБК в сыворотке крови птицы осуществляли методом иммуноферментного анализа (ИФА). Постановку реакции проводили согласно инструкции к «Набору для определения антител к вирусу инфекционного бронхита кур иммуноферментным методом при тестировании сывороток в одном разведении» (производство ФГБУ «Федеральный центр охраны здоровья животных», г. Владимир).

Учёт результатов ИФА проводили на анализаторе иммуноферментном «Infinite F50» при длине волны 405 нм с использованием компьютерной программы «Magellan for F50 V7.0». Пробы сывороток крови, содержащие антитела в титре 1:725 и выше, считались положительными. Напряжённость поствакцинального иммунитета вычисляли по отношению числа положительных проб к общему числу исследованных сывороток, выраженному в процентах.

\section{Результаты и обсуждение}

В течение 2017-2018 гг. методом ИФА было исследовано 1324 пробы сывороток крови от птицы разного возраста на выявление антител к инфекционному бронхиту кур. Поствакцинальные антитела обнаружены в 1317 пробах (99,4\%). Из ГУП РК «УОППЗ им. Фрунзе» исследовано 1110 проб, из них 1104 положительные (99,4\%), из ООО СП «Октябрьское» исследовано 214 проб, из них 213 проб положительные (99,5\%). Результаты серологических исследований сывороток крови от птицы к ИБК представлены в таблице 1.

В результате проведения эпизоотологического обследования птицеводческих хозяйств (ГУП РК «УОППЗ им. Фрунзе» и ООО СП «Октябрьское»), анализа сопроводительной документации и схем вакцинаций установлено, что эпизоотическая ситуация касательно ИБК контролируется за 
Таблица 1 - Результаты серологических исследований к вирусу ИБК

\begin{tabular}{|l|c|c|c|}
\hline \multicolumn{1}{|c|}{ Наименование организации } & $\begin{array}{c}\text { Исследовано } \\
\text { проб, шт. }\end{array}$ & $\begin{array}{c}\text { Количество положительных } \\
\text { проб, шт. }\end{array}$ & $\begin{array}{c}\text { Напряжённость } \\
\text { иммунитета, \% }\end{array}$ \\
\hline ГУП РК «УОППЗ им. Фрунзе» & 1110 & 1104 & 99,4 \\
\hline ООО СП «Октябрьское» & 214 & 213 & 99,5 \\
\hline ИтогО & $\mathbf{1 3 2 4}$ & $\mathbf{1 3 1 7}$ & $\mathbf{9 9 , 4}$ \\
\hline
\end{tabular}

счёт плановых профилактических вакцинаций, соблюдения биологической безопасности и выполнения ветеринарно-санитарных мероприятий в полном объёме.

С целью профилактики инфекционных болезней в данных хозяйствах проводят вакцинацию птицы с суточного возраста по разработанным технологическим схемам от таких болезней, как: болезнь Марека, инфекционная бурсальная болезнь, инфекционный бронхит кур, ньюкаслская болезнь, инфекционный ларинготрахеит, пнев- мовирус птиц, инфекционный энцефаломиелит, оспа птиц и синдром снижения яйценоскости-76.

ГУП РК «УОППЗ им. Фрунзе» имеет статус племенного репродуктора по разведению кур яичного направления кросса «Хайсекс Белый» и «Хайсекс Коричневый». Поголовье птицы в среднем составляет 150 тысяч голов. Для специфической профилактики ИБК на предприятии используют живые и инактивированные вакцины производства «Интервет Итернешнл Б.В.» (Нидерланды) по разработанной в хозяйстве схеме (табл. 2).

Таблица 2 - Технологическая схема вакцинации против ИБК в ГУП РК «УОППЗ им. Фрунзе»

\begin{tabular}{|c|c|c|}
\hline Возраст птицы & Наименование вакцины & Метод вакцинации \\
\hline 1 сутки & Нобилис IB Ma5 & Крупнокапельный спрей \\
\hline 10 суток & Нобилис IB 4/91 & Спрей \\
\hline 16-18 суток & Нобилис Ma5+Clon30 & Спрей \\
\hline 38-40 суток & Нобилис Ma5+Clon30 & Спрей \\
\hline 70 суток & Нобилис Ma5+Clon30 & Спрей \\
\hline 80 суток & Нобилис IB 4/91 & Спрей \\
\hline 95-100 суток & Нобилис IBmulti+ND+EDS & Внутримышечно \\
\hline
\end{tabular}

Живая вакцина «Нобилис IB Ма5» содержит штамм Ма5 вируса ИБК серотипа Массачусетс. Вакцина вызывает формирование иммунного ответа к вирусу ИБК через 5-7 дней, который сохраняется не менее 6 недель.

Живая вакцина «Нобилис IB 4/91» содержит штамм 4/91 вируса ИБК серотипа 4/91. Вакцина вызывает формирование иммунного ответа через 14 суток, который сохраняется не менее 6 недель.

Живая двухвалентная вакцина «Нобилис Ma5+Clon30» содержит штамм вируса ИБК Ма5 серотипа Массачусетс, а также лентогенный штамм вируса болезни Ньюкасла Clon-30. Вакцина вызывает формирование иммунного ответа к вирусу ИБК и НБ через 5-7 суток, который сохраняется не менее 6 недель.
Инактивированная трёхвалентная вакцина «Нобилис IBmulti+ND+EDS» содержит штаммы вирусов ИБК M41 и 249g, болезни Ньюкасла «Clon30», а также антиген вируса синдрома снижения яйценоскости-76, штамм ВС14. Вакцина вызывает формирование иммунного ответа к возбудителям ИБК, НБ и ССЯ-76 через 28 суток, который сохраняется в течение всего продуктивного периода птицы и передаётся потомству от вакцинированных родителей.

Контроль напряжённости группового иммунитета птицы к ИБК в хозяйстве начинают с 5-дневного возраста, затем проводят в 1,5 и 5 месяцев, а в последующем - один раз в 3-4 недели.

Результаты, полученные при исследовании сывороток крови от кур из ГУП РК «УОППЗ им. Фрунзе» на наличие антител к ИБК, свиде- 
тельствуют о стабильном групповом иммунитете после применения живых и инактивированных вакцин (рис. 1, табл. 3).

Как видно из рисунка 1 и таблицы 3, самые низкие титры антител отмечены у 5-суточных цыплят - 3568, затем наблюдается плавное повышение титров антител с пиком в 140-дневном

возрасте - 13866. Двукратное повышение титров антител у кур в 204-дневном возрасте до 9641 и у кур 317-дневного возраста до 12697 может свидетельствовать о воздействии «полевого» вируса ИБК.

Из данных таблицы 3 следует, что напряжённость иммунитета во всех возрастных группах

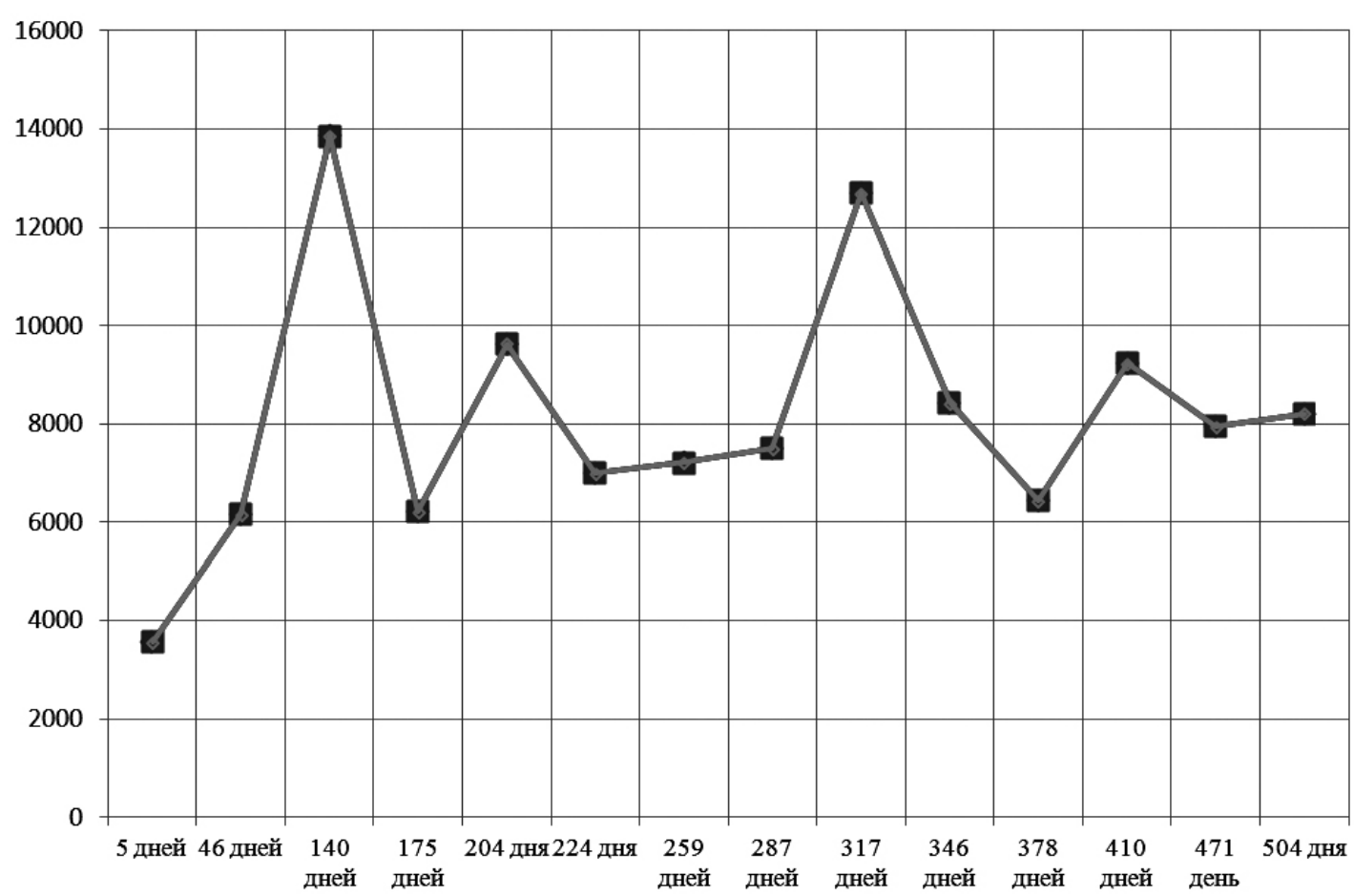

Рисунок 1 - Динамика уровня средних титров антител к вирусу ИБК у кур разных возрастных групп из ГУП РК «УОПП им. Фрунзе»

Таблица 3 - Средние титры антител к вирусу ИБК у птиц разных возрастов в ГУП РК «УОППЗ им. Фрунзе»

\begin{tabular}{|c|c|c|}
\hline Возраст птицы, сутки & Средний титр антител & Напряжённость иммунитета, \% \\
\hline 5 & 3568 & 97,1 \\
\hline 46 & 6160 & 100,0 \\
\hline 140 & 13866 & 100,0 \\
\hline 175 & 6224 & 100,0 \\
\hline 204 & 9641 & 100,0 \\
\hline 224 & 6995 & 99,0 \\
\hline 259 & 7213 & 100,0 \\
\hline 287 & 7499 & 100,0 \\
\hline 317 & 12697 & 100,0 \\
\hline 346 & 8428 & 100,0 \\
\hline 378 & 6439 & 100,0 \\
\hline 410 & 9235 & 100,0 \\
\hline 471 & 7953 & 100,0 \\
\hline 504 & 8217 & 100,0 \\
\hline
\end{tabular}

Контроль эффективности вакцинопрофилактики инфекционного бронхита кур в птицеводческих хозяйствах Республики Крым 
была на уровне 99-100\%, за исключением группы цыплят 5-суточного возраста, у которых уровень материнского иммунитета составил 97,1\%, что свидетельствует о высоком уровне защитных антител.

Таким образом, при анализе результатов можно сделать вывод, что групповой иммунитет к ИБК у птицы из ГУП РК «УОППЗ им. Фрунзе» довольно высокий (от 97,1 до 100\%), титры антител варьируют от 3568 до 13866 за счёт использования различных комбинаций вакцин и увеличения количества вакцинаций. Считается, что повторные прививания птицы различными штаммами создают более эффективную защиту против большого разнообразия антигенных вариантов вируса ИБК и защищают птицу на весь период яйценоскости.
ООО СП «Октябрьское» Красногвардейского района специализируется на разведении сельскохозяйственной птицы кросса «Хайсекс Белый», «Хайсекс Коричневый» и «Декалб Уайт» яичного направления. Поголовье составляет в среднем 300 тыс. кур-несушек.

Для специфической профилактики ИБК на предприятии используют живые и инактивированные вакцины зарубежного производства «Интервет Итернешнл Б.В.» Нидерланды (вакцины серии Нобилис), «Laboratorios Hipra, S.A.» Испания (Ависан мульти) и отечественного производства НПП «Авивак» Россия (Авивак-ИБК Н-120) по разработанной в хозяйстве технологической схеме (табл. 4).

Живая вакцина «Нобилис IB Ма5» содержит штамм Ма5 вируса ИБК серотипа Массачусетс.

Таблица 4 - Технологическая схема вакцинации против ИБК в ООО СП «Октябрьское»

\begin{tabular}{|c|c|c|}
\hline Возраст птицы & Наименование вакцины & Метод вакцинации \\
\hline 1 сутки & Нобилис ІВ Ма5 & Спрей \\
\hline 16 суток & Авивак-ИБК Н-120 \\
\hline 30 суток & Нобилис IB 4/91 & Спрей \\
\hline $70-75$ суток & Авивак-ИБК Н-120 & Спрей \\
\hline 85 суток & Нобилис ІВ 4/91 & Спрей \\
\hline $100-110$ суток & Ависан мульти & Внутримышечно \\
\hline
\end{tabular}

Вакцина вызывает формирование иммунного ответа к вирусу ИБК через 5-7 дней, который сохраняется не менее 6 недель.

Живая вакцина «Авивак-ИБК Н-120» изготовлена из штамма «Н-120» вируса ИБК серотипа Массачусетс. Иммунитет у вакцинированных цыплят формируется в течение 2-3 недель после второй вакцинации и сохраняется не менее 3-х месяцев.

Живая вакцина «Нобилис IB 4/91» содержит штамм 4/91 вируса ИБК серотипа 4/91. Вакцина вызывает формирование иммунного ответа через 14 суток, который сохраняется не менее 6 недель.

Инактивированная трёхвалентная вакцина «Ависан мульти» против синдрома снижения яйценоскости-76, ньюкаслской болезни и инфекционного бронхита. Вакцина содержит вирус инфекционного бронхита (штамм Н52), ньюкаслской болезни (штамм «Ла-Сота»), синдрома снижения яйценоскости-76 (штамм «127»). Вакцина вызывает формирование иммунного ответа через 21 сутки после однократного применения, который сохраняется в течение 65 недель.

Для определения уровня специфических антител к вирусу ИБК сыворотку крови исследуют один раз в 2-3 месяца.

Результаты, полученные при исследовании сывороток крови от кур из ООО СП «Октябрьское» на наличие антител к ИБК, свидетельствуют о стабильном групповом иммунитете после применения живых и инактивированных вакцин (табл. 5, рис. 2).

При исследовании сывороток крови от кур из ООО СП «Октябрьское» напряжённость группового иммунитета к вирусу ИБК составила от 95\% у цыплят 60-дневного возраста до 100\% у остальных возрастов, что означает эффективную защиту поголовья птицы к данному заболеванию на протяжении всего периода продуктивности.

При анализе динамики уровня среднего титра антител (рис. 2) наблюдалась тенденция варьирования титра антител от 2731 с напряжённостью иммунитета 95\% у цыплят 60-дневного 
Таблица 5 - Средние титры антител к вирусу ИБК у птиц разных возрастов в ООО СП «Октябрьское»

\begin{tabular}{|c|c|c|}
\hline Возраст птицы, сутки & Средний титр антител & Напряжённость иммунитета, \% \\
\hline 3 & 3609 & 100 \\
\hline 5 & 2750 & 100 \\
\hline 60 & 2731 & 95 \\
\hline 120 & 9204 & 100 \\
\hline 150 & 10892 & 100 \\
\hline 210 & 4721 & 100 \\
\hline 270 & 6692 & 100 \\
\hline 330 & 8752 & 100 \\
\hline 420 & 3675 & 100 \\
\hline
\end{tabular}

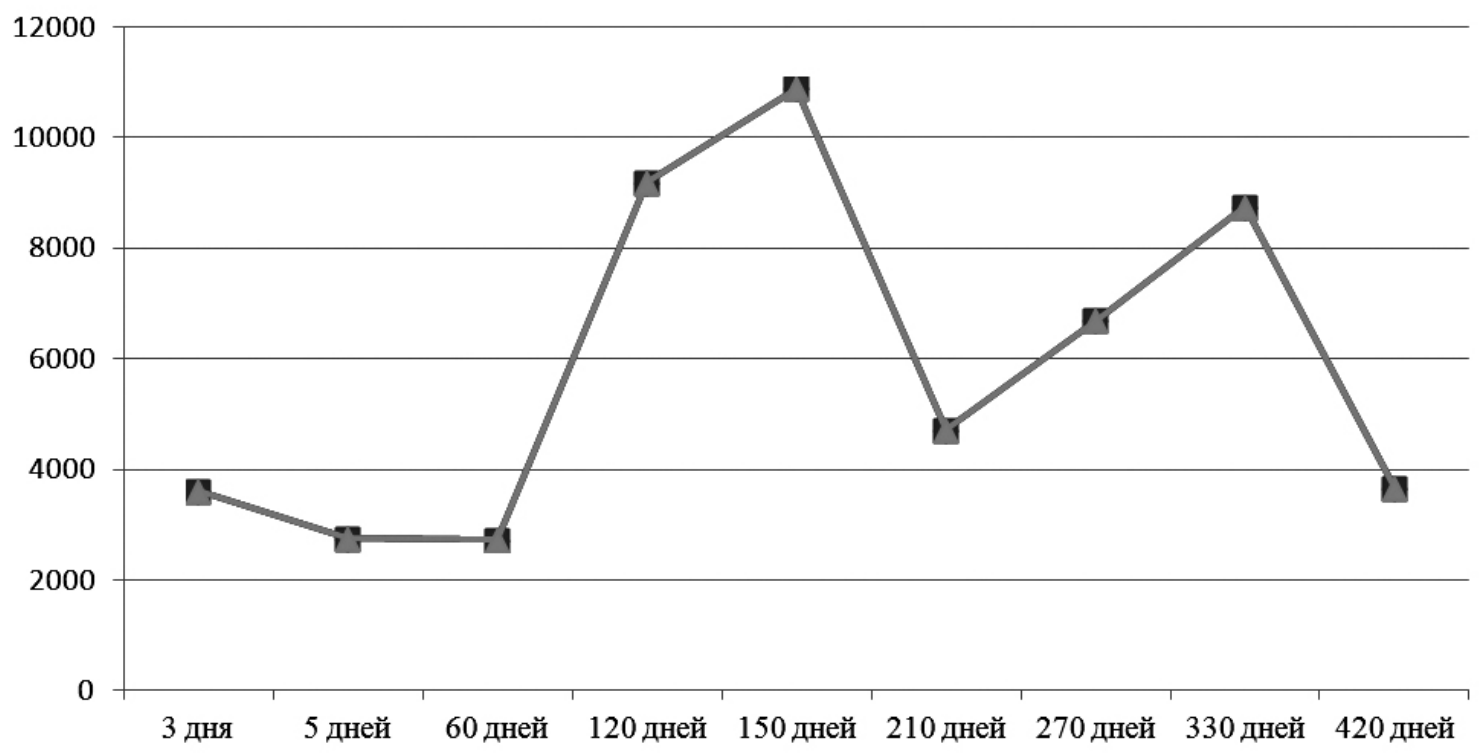

Рисунок 2 - Динамика уровня средних титров антител к вирусу ИБК у кур разных возрастных групп из ООО СП «Октябрьское»

возраста до 10892 у кур 150-дневного возраста с напряжённостью иммунитета $100 \%$.

Повышение титра антител у кур в 330-дневном возрасте до 8752 может свидетельствовать о воздействии «полевого» вируса ИБК.

На основании проведённых исследований на наличие поствакцинальных антител к ИБК на двух предприятиях установлен достаточно высокий групповой иммунитет $(99,4 \%)$ после применения живых и инактивированных вакцин, который создаёт полноценную защиту поголовья кур с суточного возраста до окончания продуктивного периода. Но необходимо отметить, что вирус ИБК имеет множественность генотипов, и иммунитет, сформированный к одному серотипу, слабо защищает против инфекции, вызванной гете- рологичным серотипом. Поэтому необходимо постоянно контролировать напряжённость иммунитета к ИБК путём регулярного проведения серологического мониторинга.

\section{Заключение}

За период с 2017 по 2018 гг. было исследовано 1324 пробы сывороток крови птиц из двух ведущих птицеводческих хозяйств Республики Крым на наличие антител к вирусу ИБК.

При проведении анализа сопроводительной документации и схем вакцинаций в обследованных хозяйствах установлено, что у кур были выявлены поствакцинальные антитела в 99,4\% проб. По результатам исследований сывороток крови от кур разных возрастных групп отмечено, 
что начиная с 5-суточного возраста происходит постепенное нарастание средних титров антител у птиц каждой следующей возрастной группы с пиком в 140- и 150-дневном возрасте.

Установлено, что применение живых и инактивированных вакцин против вируса ИБК в соответствии с действующим регламентом вакцинопрофилактики и разработанными в хозяйствах технологическими схемами вакцинации создаёт полноценную специфическую защиту у вакцинированного поголовья на протяжении всего периода продуктивности.

Перспективой дальнейших исследований является постоянный контроль уровня материнских и поствакцинальных антител к вирусу ИБК, что позволит и дальше контролировать эпизоотическую ситуацию к данному заболеванию в птицеводческих хозяйствах Крыма.

\section{Лumepamypa}

1. Серова, Н.Ю. Инфекционный бронхит кур (обзор) [Текст] / Н.Ю. Серова, Э.Д. Джавадов, Д.Т. Гоголадзе // Международный вестник ветеринарии. - 2016. - № 3. - С. 14-19.

2. Борисов, А.В. Инфекционный бронхит кур: особенности эпизоотологии и профилактики [Текст] / A.B. Борисов, В.В. Борисов // Farm Animals. - 2014. - № 1. - C. 72-74.

3. Гирин, М. Профилактика инфекционного бронхита кур [Текст] / М. Гирин, Д. Лозовой // Птицеводство. - 2009. - № 10. - С. 49-50.

4. Серова, Н.Ю. Индикация и идентификация изолятов вируса инфекционного бронхита кур, циркулирующих на территории Российской Федерации [Текст]: дисс. ... кандидата ветеринарных наук: 06.02 .02 / Серова Наталья Юрьевна. - СПб., 2017. - 106 с.

5. Немашкало, А.Ю. Моніторинг епізоотичної ситуації інфекциійного бронхіту курей [Текст] / А.Ю. Немашкало // Наукові доповіді НУБІП України. - 2014. - № 2 (44). - С. 11-15.

6. Джээнбаева, С.А. Серологический мониторинг инфекционного бронхита кур [Текст] / С.А. Джээнбаева, А.Э. Асанова // Вестник Кыргызского национального аграрного университета им. К.И. Скрябина. 2016. - № 1 (37). - C. 181-184.

\section{References}

1. Serova, N.Yu. Infekcionnyj bronhit kur (obzor) [Tekst] / N.Yu. Serova, Eh.D. Dzhavadov, D.T. Gogoladze // Mezhdunarodnyj vestnik veterinarii. - 2016. - № 3. - S. 14-19.

2. Borisov, A.V. Infekcionnyj bronhit kur: osobennosti jepizootologii i profilaktiki [Tekst] / A.V. Borisov, V.V. Borisov // Farm Animals. - 2014. - № 1. - S. 72-74.

3. Girin, M. Profilaktika infekcionnogo bronhita kur [Tekst] / M. Girin, D. Lozovoj // Pticevodstvo. - 2009. № $10 .-$ S. 49-50.

4. Serova, N.Yu. Indikacija i identifikacija izoljatov virusa infekcionnogo bronhita kur, cirkulirujushhih na territorii Rossijskoj Federacii [Tekst]: diss. ... kandidata veterinarnyh nauk: 06.02.02 / Serova Natal'ja Yur'evna. SPb., 2017. - $106 \mathrm{~s}$.

5. Nemashkalo, A.Yu. Monitoring epizootichnoï situaciï infekciijnogo bronhitu kurej [Tekst] / A.Yu. Nemashkalo // Naukovi dopovidi NUBIP Ukraïni. - 2014. - № 2 (44). - S. 11-15.

6. Dzhehehnbaeva, S.A. Serologicheskij monitoring infekcionnogo bronhita kur [Tekst] / S.A. Dzhehehnbaeva, A.Eh. Asanova // Vestnik Kyrgyzskogo nacional'nogo agrarnogo universiteta im. K.I. Skryabina. - 2016. - № 1 (37). - S. 181-184. 